\title{
The indian vision of technology
}

Baidyanath Saraswati

\section{(2) OpenEdition}

\section{Journals}

Electronic version

URL: https://journals.openedition.org/tc/769

DOI: $10.4000 /$ tc.769

ISSN: 1952-420X

\section{Publisher}

Éditions de l'EHESS

\section{Printed version}

Date of publication: 1 October 1990

ISSN: 0248-6016

\section{Electronic reference}

Baidyanath Saraswati, "The indian vision of technology", Techniques \& Culture [Online], 14 | 1990, Online since 16 January 2006, connection on 29 September 2022. URL: http://journals.openedition.org/tc/ 769 ; DOI: https://doi.org/10.4000/tc.769

This text was automatically generated on 29 September 2022

All rights reserved 


\section{The indian vision of technology}

Baidyanath Saraswati 